\title{
Phase III: Implementation and Operation of the Repository
}

\author{
Quarterly Report \\ October 1 - December 31, 1997
}

Work Performed Under Contract No.: DE-FG22-97BC14847

\author{
For \\ U.S. Department of Energy \\ Office of Fossil Energy \\ Federal Energy Technology Center \\ P.O. Box 880 \\ Morgantown, West Virginia 26507-0880
}

By

American Geological Institute

4220 King Street

Alexandria, Virginia 22302-1502 


\section{Disclaimer}

This report was prepared as an account of work sponsored by an agency of the United States Government. Neither the United States Government nor any agency thereof, nor any of their employees, makes any warranty, express or implied, or assumes any legal liability or responsibility for the accuracy, completeness, or usefulness of any information, apparatus, product, or process disclosed, or represents that its use would not infringe privately owned rights. Reference herein to any specific commercial product, process, or service by trade

name, trademark, manufacturer, or otherwise does not necessarily constitute or imply its endorsement, recommendation, or favoring by the United States Government or any agency thereof. The views and opinions of authors expressed herein do not necessarily state or reflect those of the United States Government or any agency thereof. 


\section{NATIONAL GEOSCIENCE}

DATA REPOSITORY SYSTEM

\section{PHASE III: IMPLEMENTATION AND OPERATION OF THE REPOSITORY \\ PR OGRESS RE PORT \\ DE -F G 22-97B C -14847--04}

4th Q uarter
October-December, 1997

Submitted by the

\section{AMERICAN GEOLOGICAL INSTITUTE \\ to the}

\section{Office of F ossil Energy, U.S. Department of Energy}

\section{J anuary 1998}

American Geological Institute, 4220 King Street, Alexandria, VA 22302-1502

(703) 379-2480 Fax: (703) 379-7563 


\title{
NGDRS Phase III — Implementation Fourth Quarter Progress Report
}

\author{
January 1998
}

\section{Overview}

In October all three Sun servers (3000, Ultra/II) were loaded, and we were able to demonstrate the complete system databases, web front-page, and GeoTrek — to a large audience. All systems required for the web-based metadata catalog are in place and operational. Version 54 of the PetroTrek/GeoTrek software was loaded in December and is being tested. It is expected this version will be placed in the production environment for beta testing in January.

Installation of the Bureau of Economic Geology (BEG) databases on the IS Houston server was completed and GeoTrek was loaded on BEG's server in Austin. Installation of the entire MMS well data set (35,000 records) was completed and it will be moved to the production environment for beta testing in January. The Eastern Gulf Region PTTC interior salt basin data set was prepared and it will be loaded in January. The Gulf of Mexico PGS seismic data set was prepared and loaded in December.

The web-site front pages for the NGDRS GeoTrek Metadata Catalog are 70 percent completed and write-ups for the tutorials are scheduled to be completed in January. Ten users identified to be beta testers are actively testing the system.

\section{Program Activities Summary}

\subsection{NGDRS STEERING COMMITTEe MEETING}

Amoco hosted a meeting of the NGDRS Steering Committee at their Houston offices. The focus of the meeting was on identification of a new repository facility and status of the GeoTrek Metadata Catalog. Two facilities are presenting being evaluated for repositories - the Amoco Houston Core Repository located on Little York Road in northwest Houston and Hanger Four at Denver's former Stapleton Airport. AGI is actively pursuing both of these possibilities.

The GeoTrek Metadata Catalog was demonstrated, reviewed, and tested. The Committee was highly supportive of the GeoTrek development effort. The Committee recommended establishing two activities committees - one to address the needs for a repository facility and contributions of cores and cuttings and a second to address opportunities for loading service company databases on GeoTrek. John Deery, Amoco, will chair the Repository Core Subcommittee and Robert Merrill, Spirit of 76, will chair the GeoTrek Metadata Catalog Subcommittee. Each company was given an opportunity to discuss and review their data management issues and how they might be addressed through the NGDRS program. Minutes and handouts for the meeting are attached with this report.

\subsection{Establishing The Clearinghouse}

\section{Task 2.1 -- Project Plan and Management}

The following projects had their plan sheets updated:

\begin{tabular}{|c|c|c|}
\hline PROJECT NAME & PROJECT TYPE & PROJECT STATUS \\
\hline 1. Houston Core Facility Project & Transfer of Core and Cuttings & Underway \\
\hline 2. Well Log Data Tape Conversion Project & Transfer of Digital Data & Not defined \\
\hline 3. Seismic Data Tape Conversion Project & Transfer of Digital Data & Underway \\
\hline 4. BEG Project & Electronic Database Transfer & Underway \\
\hline 5. PGS Project & Electronic Database Transfer & COMPLETED \\
\hline 6. Kansas Geological Survey Project & Electronic Database Transfer & Delayed \\
\hline 7. Mobil Seismic Sales Project & Electronic Database Transfer & Not defined \\
\hline
\end{tabular}




\begin{tabular}{|c|c|c|}
\hline 8. Metadata Repository Infrastructure & Creation of the Metadata Repository & COMPLETED \\
\hline 9. Metadata Repository Utilization & $\begin{array}{l}\text { Utilization and Operations of the } \\
\text { Metadata Repository }\end{array}$ & Underway \\
\hline 10. Mineral Management Services (MMS) & Electronic Database Transfer & Underway \\
\hline 11. Oklahoma Geological Survey (OGS) & Electronic Database Transfer & Underway \\
\hline 12. Eastern Gulf Region PTTC & Electronic Database Transfer & Underway \\
\hline
\end{tabular}

\section{Task 2.2 -- BEG - Databases Conversion}

In preparation for installing GeoTrek at the BEG in Austin, R. Hanks completed the loading and a tiling of the two databases (cores, well log headers) in Houston during the first week in December. In addition several cultural data sets were prepared including Texas county data (Lat/Long boundary and center of county and county names). Before the installation at the BEG the assembled system (GeoTrek and data sets) was tested by the staff of The Information Store

The installation of GeoTrek at the BEG-Austin was completed on 12/12/97. Working on the installation from The Information Store were Rod Hanks and A. Eloy. Oracle technical support was provided to the team by an outside consultant -- Tom Watson. Rodney Heathcott and Morgan Ives of the BEG provided infrastructure support. The team loaded the current BEG Core Repository data and Geophysical Log data into an Oracle database and installed GeoTrek (v.54) as a browser for this data. Minor compatibility issues were encountered with the Oracle Web Server software but they were all overcame and by late afternoon the installation was completed.

The system is running under Unix (Solaris operating system) using Oracle Web (HTML) Server (v3.0). The BEG is currently testing the system with various combinations of platforms and browsers. Once they have gained familiarity with the system they plan to have users from the Core Research Center (in Austin and Midland) test it. They provide us with feedback and will work with us during our testing phase.

\section{Task 2.3 -- OGS - Databases Conversion and Installation}

We determined that the computer program "TRS2LL" that we were attempting to use for converting township/range/section data into Lat/Long data, is only applicable to certain states and that Oklahoma is not one of them. The program is made available by the BLM and the current person that is the custodian of the program has no immediate plan for expanding it. We will be reviewing the program source code (Fortran) to assess how difficult it is to extend it ourselves.

\section{Task 2.4 -- MMS - Databases Conversion and Installation}

The total Gulf of Mexico (GOM) well-wellbore data set, consisting of approximately 35,000 wellbore entries, was loaded on our development-staging computing environment. The data set was also "tiled" to allow for the loading of the data displayed on the working area of GeoTrek. The tiling of the data shows a summary of the wellbores available for the each GOM block. GeoTrek queries can be applied for further filtering the data set. This allows users to develop, for example, a tiled map for the GOM containing all wells owned by company XYZ.

\section{Task 2.5 -- Eastern Gulf Region PTTC - Databases Conversion and Installation}

This project was proposed by the NGDRS Team in November and was initiated in December.

The original data set deals with data from the Mississippi Interior Salt Basin and is available at the web site <http://egrpttc.geo.ua.edu/pttc/reports/smacko 1/contents.html>. The data set was identified by C. Keane during discussions with Ernest Mancini, a member of the Eastern Gulf PTTC. The set is part of a report aimed at providing the information obtained from a geological study of the Mississippi Interior Salt Basin. The work focused on inventorying the data files and records of the major information repositories in the Northeastern Gulf of Mexico and making these inventories easily accessible in an electronic format. The study is part of the Advanced Geologic Basin Analysis Program promoted by the DOE. The program designed to provide an avenue for studying and evaluating sedimentary basins and to improve the efficiency of the discovery of the nation's remaining undiscovered oil resources. 
The following was accomplished in December:

- Export of the original files from HTML to ASCII format.

- Merging of the original 15 data sets, that were split by county, into one single data set.

- Identification of the data schema, unique keys and data issues. The following is a summary of our findings:

- The unique data set key is the Permit Number, not the API number. The same API number appears repeated on different permits. Furthermore, the API numbers ending with 20000 (such as API\#=01-097-20000) appears repeated many times; it seems to be a "catch-all number" used to describe water disposal wells.

- There are approximately 1,200 permit numbers (rows in the table).

- About 3\% of the 1,200 entries did not have Lat/Long data. We have approximated the Lat/Long data from the "nearby" permits or through interpolated values. All entries in our file have a Lat/Long. A column was added describing how the approximation was obtained.

- The data set is a fairly rich metadata data set containing information on what well logs were taken, what king of samples are available, well status, etc.

\subsection{Creating The Metadata Repository}

\section{Task 3.1 -- Sun Microsystems}

No work or problems to report.

\section{Task 3.2 -- Internet Software Components Development and Installation}

The development of the front-end pages of NGDRS web site continued. The list below gives a brief status of this work by the end of November:

$\begin{array}{ll}\text { SECTION OF WEB SITE } & \underline{\text { STATUS }} \\ \text { About the NGDRS project } & \begin{array}{l}\text { completed } \\ \text { completed }\end{array} \\ \text { What's New (1997) } & \text { started } \\ \text { NGDRS Installed Data Sets } & \text { completed } \\ \text { What's Planned (1998 and beyond) } & \text { completed } \\ \text { Site Purpose and Intended Audience } & \text { started } \\ \text { Tutorials } & \text { completed } \\ \text { Frequently Asked Questions (FAQ) } & \text { started } \\ \text { System Requirements } & \text { started } \\ \text { Contact Us } & \end{array}$

\section{Task 3.3 -- GeoTrek}

Testing continued of the new version (v.54) of the GeoTrek software, required by the NGDRS to handle large data sets. Additional features and improvements were implemented. 


\subsection{Utilizing ThE Metadata REPOSITORY}

\section{Task 4.1 -- Marketing NGDRS}

The following is an updated list of events or tasks that have been identified as part of the on-going marketing campaign:

\begin{tabular}{|c|c|c|c|c|}
\hline EVENT & WHERE & WHEN & STATUS & RESPONSIBLE \\
\hline Repositories Meeting & Calgary & June $16-17$ & Completed & TW \\
\hline DOE Contractors Workshop & Houston & June 20 & Completed & $\mathrm{MM}, \mathrm{GB}$ and $\mathrm{AE}$ \\
\hline PTTC Board Meeting & $\mathrm{DC}$ & July $13-15$ & Completed & GB \\
\hline AGI/NGDRS Review Meeting & $\begin{array}{l}\text { Houston, } \\
\text { Amoco }\end{array}$ & Oct. 15 & Completed & $\begin{array}{l}\text { JD, MM, JVS, GB, } \\
\mathrm{AE}\end{array}$ \\
\hline GSA Meeting & Salt Lake City & Oct. $20-23$ & Canceled & AGI \\
\hline SEG Annual Meeting & Dallas & Nov. 2-7 & Completed & Information Store \\
\hline AAPG - Annual/98 Meeting & Salt Lake City & May $17-20$ & Not defined & --- \\
\hline POSC/AGI Standards Workshop & DC & Not scheduled & Discussions & MM, D. Archer \\
\hline NGDRS Marketing Plan & Houston & $\mathrm{Jan} / 98$ & Not started & A. Eloy \\
\hline
\end{tabular}

\section{Task 4.2 Metadata Repository Beta-Testing}

Below is a list of people that were invited or have volunteered for testing the NGDRS system. The list includes notes on their current status and pertinent remarks.

\begin{tabular}{|c|c|c|c|c|}
\hline & PERSON & ORGANIZATION & STATUS & NOTES \\
\hline 1 & Christopher Keane & AGI & Beta-tester & \\
\hline 2. & Gary Stone & Five States Energy... & Beta-tester & \\
\hline 3 & Mary Blount & MMS-New Orleans & Beta-tester & \\
\hline 4 & Ronald Brignac & MMS-New Orleans & Beta-tester & \\
\hline 5 & George Dellagiarino & MMS-Virginia & Beta-tester & Engaged 2 more MMS people \\
\hline 6 & Madelyn Bell & Mobil & Beta-tester & \\
\hline 7 & Allen Hittelman & NOAA-Denver & Beta-tester & \\
\hline 8 & Ben Lin & Unocal & Beta-tester & \\
\hline 9 & Sherilyn Williams-Stroud & USGS-Denver & Beta-tester & \\
\hline 10 & Shawn Devlin & Viking Resources-Kansas & Beta-tester & Small independent \\
\hline 11 & Mark Aden & Pennzoil & Declined & \\
\hline 12 & Bruce Baum & Enserch & Declined & \\
\hline 13 & Lance Cole & PTTC & Delegated to person at Viking Resources & Contacted 10 more persons \\
\hline 14 & Jim Gibbs & Five States Energy. & Delegated - G. Stone & \\
\hline 15 & Del Fortner & BLM-Bakersfield & Looking for suitable volunteer at BLM & \\
\hline 16 & Tom Coffman & Visos Exploration & No answer & \\
\hline 17 & John Deery & Amoco & No answer & \\
\hline 18 & Fred Hilterman & Geophysical Develop. Corp. & No answer & \\
\hline 19 & David Jenne & Maxus & No answer & \\
\hline 20 & 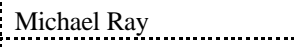 & DOE-Natl. Petroleum Tech. & No answer & \\
\hline 21 & Michael Baranovic & Shell Offshore - New Orleans & No answer & \\
\hline 22 & Robert D. Hatcher & University of Tennessee & No answer & \\
\hline
\end{tabular}

